УДК 656.13

\title{
МАТЕМАТИЧНА ФОРМАЛІЗАЦІЯ ПАРАМЕТРІВ ЯКОСТІ ПЕРЕВЕЗЕННЯ ПАСАЖИРІВ МІСЬКИМ ТРАНСПОРТОМ
}

\author{
Д-р техн. наук І.В. Чумаченко, асп. Н.В. Давідіч
}

\section{МАТЕМАТИЧЕСКАЯ ФОРМАЛИЗАЦИЯ ПАРАМЕТРОВ КАЧЕСТВА ПЕРЕВОЗКИ ПАССАЖИРОВ ГОРОДСКИМ ТРАНСПОРТОМ}

\author{
Д-р техн. наук И.В. Чумаченко, асп. Н.В. Давидич
}

\section{MATHEMATICAL FORMALIZATION OF PASSENGERS URBAN TRANSPORT PARAMETERS QUALITY}

\author{
Doct. of techn. science I. Chumachenko, post-graduate student N. Davidich
}

Проведено аналіз параметрів якості транспортного обслуговування пасажирів міським транспортом. Математично формалізовано комплексний показник якості міського пасажсирського транспорту. Визначено, щуо зміна часу простою пасажирів $у$ транспортному засобі на зупинному пункті маршруту з достатньою точністю описується нелінійним регресійним рівнянням, в якому як змінні використовуються кількість та ширина дверей, пасажсирообмін зупинок, коефіцієнт використання місткості.

Ключові слова: пасажир, перевезення, якість, модель, технологія, транспорт, час очікування, зупинний пункт.

Проведен анализ параметров качества транспортного обслуживания пассажиров городским транспортом. Математически формализован комплексный показатель качества городского пассажирского транспорта. Определено, что изменение времени простоя пассажиров в транспортном средстве на остановочном пункте маршрута с достаточной точностью описывается нелинейным регрессионным уравнением, в котором в качестве переменных используются количество и иирина дверей, пасажирообмен остановок, коэффициент использования вместимости.

Ключевые слова: пассажир, перевозка, качество, модель, технология, транспорт, время ожидания, остановочный пункт.

In this paper it is discussed the issues of assessing the public transport services quality. The main purpose of the research is mathematical formalization of transportation passengers' quality parameters. It is analyzed the transport service of public transport passengers' quality parameters. It has been found that the main indicator of the quality parameters of a trip passengers. Mathematically it is formalized a comprehensive index of quality of urban passenger transport, taking into account the importance of the quality indicators of the passengers when the trip itinerary. It is used the statistical methods to assess complex objects which allows take into account the stochastic transport process in the process of development of urban transport projects. It is demonstrated the technique of carrying out full-scale survey of passengers travel options. It has been determined that a change in downtime of the vehicle on the stopping point of the route with sufficient accuracy by the nonlinear regression equation which is used as a variable number and width of doors in a vehicle, the utilization rate of the vehicle capacity. This makes it possible to assess the various options for urban transport projects in the interests of transport companies and 
passengers. The research results can be applied by experts in the field of passenger transportation in the urban project management report.

Keywords: passenger, freight, quality, model, technology, transportation, waiting time, the stopping point.

Вступ. Однією 3 найважливіших складових міської інфраструктури, без якої неможливе нормальне існування сучасного великого міста, $\epsilon$ міська пасажирська транспортна система. Міський пасажирський транспорт загального користування $є$ найважливішою складовою життєдіяльності міста, основною задачею якого $є$ своєчасне, якісне та повне задоволення потреб у перевезеннях пасажирів. Він $є$ одним 3 важливих чинників забезпечення життєдіяльності населення України. На його частку припадає більше 85-90\% усіх перевезень у містах [1]. Ефективна i надійна робота міського пасажирського транспорту $\epsilon$ найважливішим чинником соціальноекономічної стабільності. В кризовій ситуації сьогодення необхідним $\epsilon$ підвищення швидкості сполучення i комфортності поїздок 3 урахуванням платоспроможності населення. Якість надання послуг міським пасажирським транспортом багато в чому визначає забезпечення трудової діяльності, культурного розвитку та відпочинку населення.

Існуючий рівень пасажирських перевезень не відповідає сучасним вимогам, що ставляться до якості перевезення пасажирів. При цьому часто не забезпечується передбачений нормами час поїздок, що пояснюється низькими швидкостями сполучення основними видами міського пасажирського транспорту, необхідністю виконувати пересадки 3 причини недосконалої маршрутної мережі та витратами часу на підходи до зупинних пунктів [2]. Перевезення пасажирів міським пасажирським транспортом має здійснюватися 3 найбільшими зручностями, безпечно і 3 можливо меншою витратою часу на поїздку. Це потребує проектування якості транспортного обслуговування мешканців міста. Управління якістю складається 3 процесів, які гарантують, що продукт проекту, а також сам проект задовольнятимуть ті потреби учасників, заради яких він створювався. Управління якістю в сучасних проектах здійснюється на всіх стадіях і охоплює всі його сторони [3]. Якість обслуговування пасажирів, які користуються міським пасажирським транспортом, $\epsilon$ важливою соціальною i економічною задачею для кожного міста.

Аналіз останніх досліджень і публікацій. Підвищення якості пасажирських перевезень у системі міського пасажирського транспорту - один 3 найважливіших напрямків, поставлених перед потребами суспільства у галузі транспорту [4-6]. Оцінку якості пасажирських перевезень на міському пасажирському транспорті, на думку дослідників, необхідно проводити для того, щоб можна було вирішити такі задачі, як визначення та уточнення вимог до якості перевезень для даного міста на основі систематичного вивчення підвищення вимог до якості та досягнення у галузі управління якістю, розроблення організаційно-технічних заходів 3 удосконалення транспортного виробництва на усіх ділянках 3 метою досягнення установлених нормативів якості, контроль за реалізацією розроблених заходів та залучення системи управління якістю перевезень пасажирів на міському пасажирському транспорті.

На думку дослідників, одним 3 найбільш суттєвих критеріїв оцінки якості транспортного обслуговування населення $\epsilon$ загальні витрати часу жителів на пересування від початкового пункту до кінцевого [7]. Інші дослідники додатково 
характеризують якість роботи міського пасажирського транспорту коефіцієнтом випуску засобів транспорту на лінію, коефіцієнтом наповнення, коефіцієнтом використання часу в наряді, швидкістю сполучення, інтенсивністю руху, інтервалом руху, коефіцієнтом регулярності, показником ефективності обслуговування, коефіцієнтом ефективності витрат, узагальненим показником якості роботи $[2,4,8,9]$. Також науковці враховують тяжкість дорожньо-транспортних пригод [10].

До середини 90-х років минулого століття дослідниками як основний показник якості використовувався коефіцієнт якості, який визначається як відношення величини витрат часу на поїздку за заданих теоретично абсолютно комфортних умов поїздки до фактичних витрат часу на поїздку в реальних умовах [11]. На додаток до цього науковці у своїх роботах [12] рекомендують визначати показник якості транспортного обслуговування в містах 3 урахуванням нормативу часу, що витрачається пасажиром на поїздку; часу, що фактично витрачається пасажиром на поїздку; нормативного коефіцієнта наповнення; фактичного значення коефіцієнта наповнення; показника регулярності руху. Інші дослідники в роботі [13] розвивають поняття комплексного або інтегрованого показника якості, що враховує різні фактори обслуговування пасажирів.

Для оцінки комплексним показником якості пасажирських автотранспортних послуг, на думку дослідників, доцільно використовувати середнє арифметичне зважене одиничних показників [14]. При цьому планування якості процесу перевезення на маршрутах міського пасажирського транспорту базується на визначенні вагомості окремих показників якості. Загальне керування якістю в широкому розумінні, зазначають науковці, найкраще можна зрозуміти, розглянувши почуття покупця, який $\epsilon$ споживачем послуг. Тут одним 3 головних факторів може бути час виконання послуги. Щодо споживачів, то якість - це ступінь відповідності системи обслуговування вимогам, специфікаціям i очікуванням споживачів [15]. Існуючі методи оцінки якості в проектах міського пасажирського транспорту не повністю враховують суб'єктивну оцінку пасажирами умов обслуговування $[16,17]$.

Затвердження якості проекту відбувається за допомогою таких процедур, як гарантія якості, аудити проекту і його продукту. Там, де це доречно, дослідники використовують

автоматизоване проектування та створення необхідних моделей [3]. Однак у науковій літературі щодо оцінки якості міського пасажирського транспорту ще не знайшло достатнього відображення моделювання параметрів якості перевезення пасажирів для планування цього показника. Як вказують науковці, основним параметром якості $\epsilon$ загальні витрати часу пасажира, які складаються з часу на підхід до зупинки, часу очікування пасажиром транспортного засобу, тривалості посадки та руху в ньому, а також часу руху пішки до кінцевого пункту [11]. При цьому час руху в транспортному засобі складається 3 часу руху в ньому на перегонах маршруту та часу простою на зупинних пунктах.

Визначення мети та задачі дослідження. Проведені дослідження ставили за мету провести математичну формалізацію комплексного показника якості міського пасажирського транспорту i тривалості часу простою пасажирів $\mathrm{y}$ транспортному засобі на зупинних пунктах.

Для досягнення поставленої мети вирішувалися такі задачі:

- проведення натурного обстеження 3 метою фіксації значущості для пасажирів критеріїв якості роботи міського пасажирського транспорту;

- формалізація комплексного показника якості міського пасажирського транспорту 3 урахуванням суб' єктивної оцінки пасажирами умов обслуговування; 
- проведення натурного обстеження 3 метою фіксації тривалості та умов простою пасажирів у транспортному засобі на зупинних пунктах;

- статистична обробка отриманих даних 3 метою визначення залежності між значенням часу простою пасажирів у транспортному засобі на зупинних пунктах та умовами його виконання.

Основна частина дослідження. Значущість для пасажирів параметрів якості транспортного обслуговування міським транспортом визначалася на підставі даних натурного обстеження. Воно полягало в опитуванні пасажирів щодо параметрів перевезення, якими вони оцінюють якість виконання пересування. При цьому пасажири повинні були оцінити ці параметри за значущістю. Загалом пасажирами було виділено тринадцять показників. Для оцінки узгодженості думок експертів було використано коефіцієнт конкордації Кендела. Для перевірки статистичної ваги коефіцієнта конкордації було розраховано емпіричне значення критерію Пірсона.

Було виявлено, що при оцінці якості міського пасажирського транспорту для пасажирів у першу чергу важливим $\epsilon$ час руху. Другим за значущістю чинником $\epsilon$ час очікування транспорту. Менш значущими виявилися критерії: поїздка без пересадки, час руху до зупинного пункту, комфортабельність, місткість, наповнюваність, безпека руху, зовнішній вигляд транспорту та чистота салону, час простою на проміжних зупинках, культура обслуговування, зручність висадки- посадки, технічне транспортного засобу, обладнання альтернативних способів пересування, наявність пільг та екологічність транспортного засобу.

Для оцінки якості транспортного обслуговування пасажирів 3 тринадцяти факторів було відібрано чотири основних показники, які можна використовувати при плануванні якості проектів міського пасажирського транспорту:

- час пішохідної складової транспортних пересувань, який включає час підходу та відходу від зупинки;

- час очікування транспортного засобу;

- час поїздки;

- динамічний коефіцієнт використання місткості транспортного засобу.

Врахування ступеня значущості для пасажирів визначених параметрів проводилося з використанням величини їх рангів. Допускаючи, що максимальне значення коефіцієнта якості дорівнює одиниці, було розраховано відповідні коефіцієнти вагомості одиничних показників якості при виконанні маршрутної поїздки:

- пішохідна складова транспортних пересувань $x_{n м}=0,137$;

- час очікування $x_{o ч}=0,262$;

- час поїздки $x_{\text {поїд }}=0,465$;

- динамічний коефіцієнт використання місткості $x_{\kappa . в . м}=0,136$.

Внаслідок цього, комплексний показник якості міського пасажирського транспорту може мати такий вигляд:

$$
K_{r}^{\text {марир }}=\left(\frac{t_{n u_{\min }}}{t_{n u_{\phi}}}\right)^{0,137} \cdot\left(\frac{t_{o u_{\min }}}{t_{o \psi}}\right)^{0,262} \cdot\left(\frac{t_{n_{\min }}}{t_{n_{\phi}}}\right)^{0,465} \cdot\left(\frac{\gamma_{\partial_{\min }}}{\gamma_{\partial_{\phi}}}\right)^{0,136},
$$

де 0,$137 ; 0,262 ; 0,465 ; 0,136$ - коефіцієнти вагомості одиничних показників при виконанні маршрутної поїздки;

$$
t_{n_{\min }} \text { - мінімально можливий час }
$$
поїздки, хв; 
$t_{n_{\phi}}-$ фактичний час поїздки, хв;

$\gamma_{\partial_{\min }}-$ динамічний коефіцієнт використання місткості 3 урахуванням міст для сидіння;

$\gamma_{\partial_{\phi}}-$ фактичний динамічний коефіцієнт використання місткості транспортного засобу;

$t_{n u_{\min }}-$ мінімальний час пішохідної складової транспортного пересування, хв;

$t_{n u_{\phi}}$ - фактичний час пішохідної складової транспортного пересування, хв;

$t_{o u_{\text {min }}}$ - мінімальний час очікування, хв;

$t_{o u_{\phi}}-$ фактичний час очікування, хв.

При проектуванні параметрів технологічного процесу можна планувати якість транспортного обслуговування. Для цього необхідне визначення фактичних значень показників моделі (1). Для вирішення цієї задачі доцільно використовувати методи моделювання. Необхідним $є$ розроблення моделей зміни складових комплексного показника якості міського пасажирського транспорту. Даний етап дослідження включав розроблення моделі зміни складової часу поїздки - часу простою пасажирів у транспортному засобі на зупинному пункті маршруту.

Вирішення цієї задачі проводилося 3 використанням даних натурного обстеження. При його проведенні фіксувалися пасажирообмін зупинних пунктів, пасажиронаповнення транспортних засобів при прибутті на зупинні пункти і їх параметри.

Опис зміни часу простою пасажирів у транспортному засобі на зупинному пункті проводився 3 використанням методів кореляційного і регресійного аналізу [18]. Отримана модель має такий вигляд:

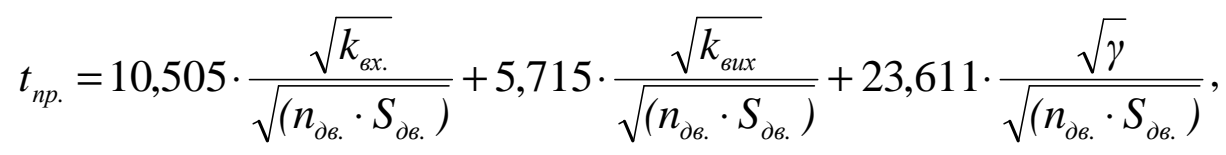

де $k_{\text {вx. }}$ - кількість пасажирів, що увійшли до транспортного засобу, пас.;

$k_{\text {виx }}$ - кількість пасажирів, що вийшли 3 транспортного засобу, пас.;

$n_{\partial \varepsilon .}-$ кількість дверей у транспортному засобі, од.;

$S_{\text {дв. }}$ - ширина дверей транспортного засобу, м;

$\gamma$ - коефіцієнт використання місткості транспортного засобу.
Параметри моделі зміни часу простою пасажирів у транспортному засобі на зупинних пунктах маршруту наведено в табл. 1-2.

3 усіх досліджуваних факторів значущими виявилися три, про що свідчать розрахункові значення критерію Стьюдента кожного коефіцієнта моделі, які перевищують табличне значення, i відсутність нуля в довірчих інтервалах коефіцієнтів моделі.

Таблиця 1

Межі вимірювання факторів моделі зміни часу простою пасажирів у транспортному засобі на зупинному пункті

\begin{tabular}{|l|c|}
\hline \multicolumn{1}{|c|}{ Фактор } & Межі вимірювання \\
\hline Кількість дверей транспортного засобу & $1-3$ \\
\hline Ширина дверей транспортного засобу & $0,82-1,2$ \\
\hline Кількість пасажирів, які увійшли & $0-70$ \\
\hline Кількість пасажирів, які вийшли & $0-80$ \\
\hline Коефіцієнт використання місткості транспортного засобу & $0-1,3$ \\
\hline
\end{tabular}


Характеристика моделі зміни часу простою пасажирів у транспортному засобі

Таблиця 2 на зупинному пункті

\begin{tabular}{|c|c|c|c|c|}
\hline \multirow{2}{*}{ Фактор } & \multirow{2}{*}{ Коефіцієнт } & \multirow{2}{*}{$\begin{array}{c}\text { Стандартна } \\
\text { помилка }\end{array}$} & \multicolumn{2}{|c|}{ Критерій Стьюдента } \\
\hline & & & розрахунковий & табличний \\
\hline 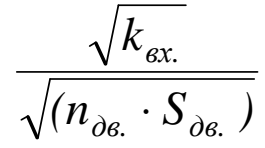 & 10,505 & 0,606 & 17,307 & \multirow{3}{*}{2,02} \\
\hline$\frac{\sqrt{k_{\theta u x}}}{\sqrt{\left(n_{\partial 6 .} \cdot S_{\partial \varepsilon .}\right)}}$ & 5,715 & 0,489 & 11,672 & \\
\hline$\frac{\sqrt{\gamma}}{\sqrt{\left(n_{\partial \sigma_{.}} \cdot S_{\partial \delta_{.}}\right)}}$ & 23,611 & 3,018 & 7,821 & \\
\hline
\end{tabular}

Оцінка статистичної значущості моделі проводилася за допомогою критерію Фішера, коефіцієнта множинної кореляції та середньої помилки апроксимації, значення яких подано у табл. 3. Значення статистичних показників відповідає допустимим межам.
Для оцінки фізичної адекватності та аналізу отриманої моделі було розроблено графіки зміни часу простою пасажирів у транспортному засобі на зупинному пункті (рис. 1-5).

Таблиця 3

Результати статистичної оцінки моделі зміни часу простою пасажирів у транспортному засобі на зупинному пункті

\begin{tabular}{|c|c|c|}
\hline \multicolumn{2}{|c|}{ Показники } & Значення \\
\hline \multirow{2}{*}{ Критерій Фішера } & розрахунковий & 522,73 \\
\cline { 2 - 3 } & табличний & 1,39 \\
\hline \multicolumn{2}{|c|}{ Коефіцієнт множинної кореляції } & 0,95 \\
\hline \multicolumn{2}{|c|}{ Середня помилка апроксимації, \% } & 8,07 \\
\hline
\end{tabular}

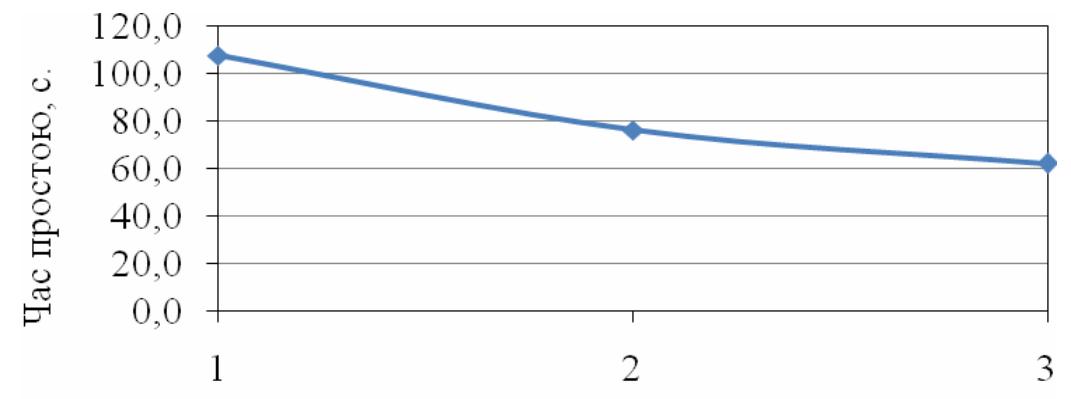

Кількість дверей, од.

Рис. 1. Зміна часу простою пасажирів у транспортному засобі залежно від кількості дверей транспортного засобу 


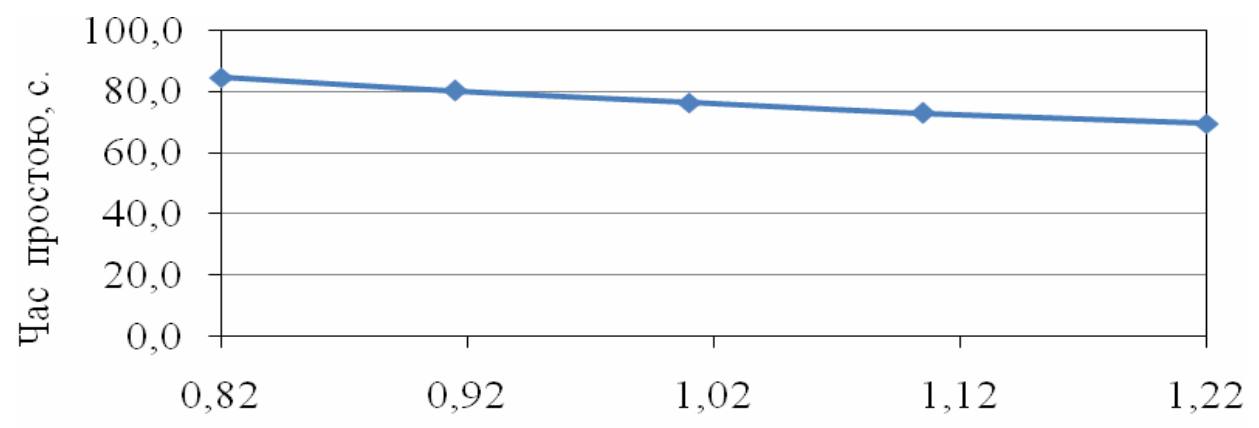

Ширина дверей транспортного засобу, м

Рис. 2. Зміна часу простою пасажирів у транспортному засобі залежно від ширини дверей транспортного засобу

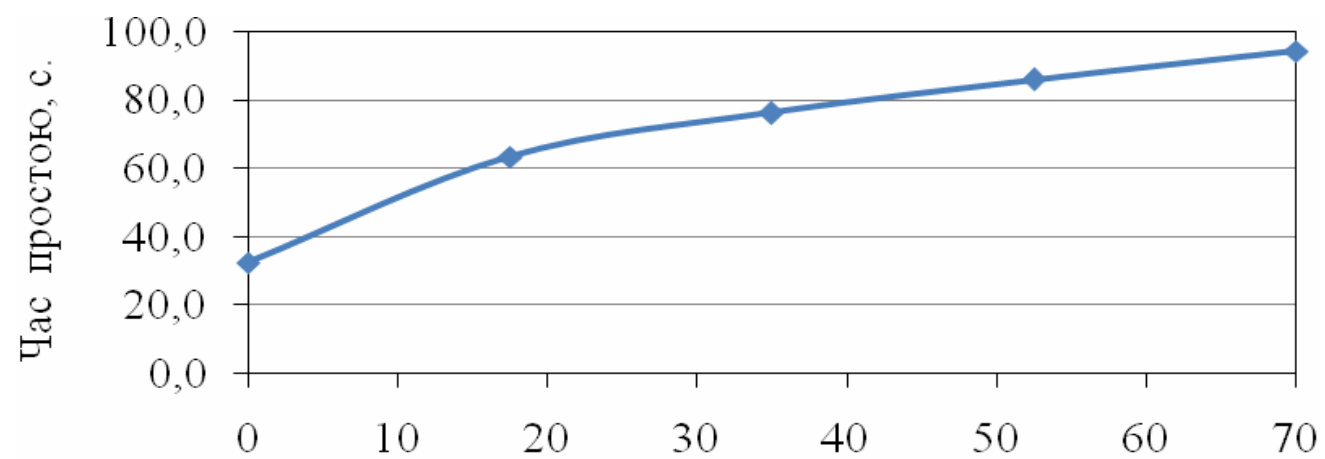

Кількість пасажирів, які увійшли, пас.

Рис. 3. Зміна часу простою пасажирів в транспортному засобі залежно від кількості пасажирів, які увійшли до транспортного засобу

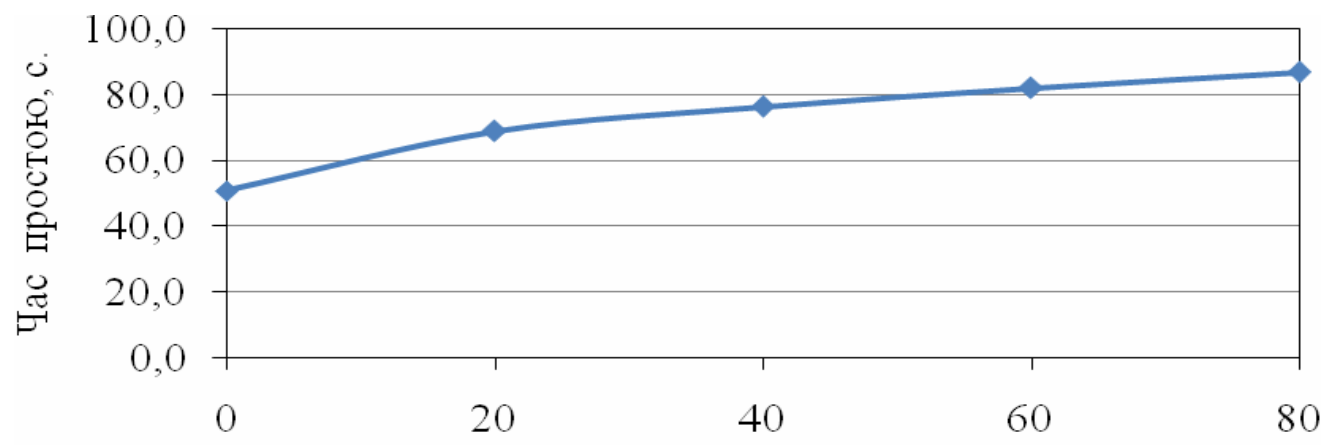

Кількість пасажирів, які вийшли, пас.

Рис. 4. Зміна часу простою пасажирів у транспортному засобі залежно від кількості пасажирів, які вийшли з транспортного засобу 


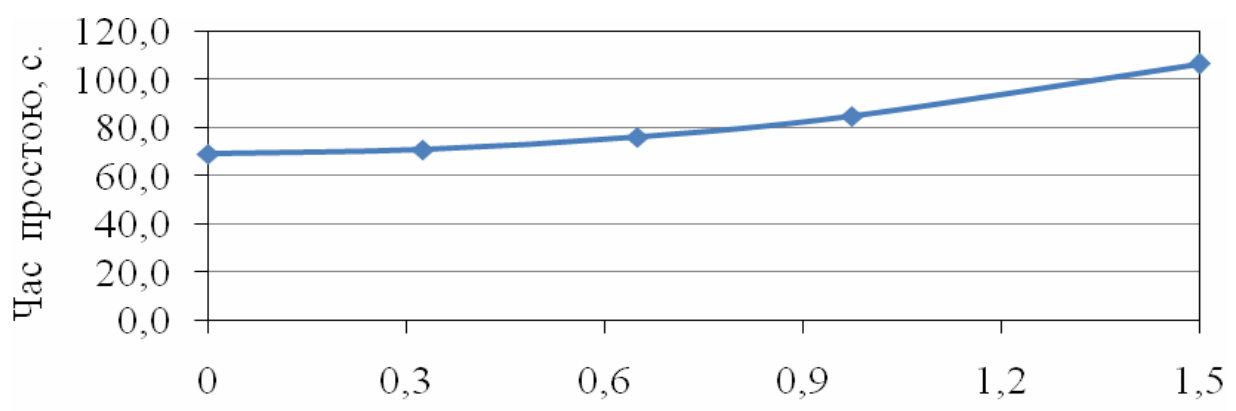

Коефіцієнт використання місткості

Рис. 5. Зміна часу простою пасажирів у транспортному засобі залежно від коефіцієнта використання місткості транспортного засобу

При побудові графіків усі фактори моделі, крім того, який досліджувався, відповідали середнім значенням. 3 аналізу моделі можна зробити такі висновки.

За рахунок збільшення кількості дверей у транспортному засобі поліпшуються умови входу і виходу пасажирів. Це дає змогу значно скоротити час на посадку і висадку пасажирів на зупинних пунктах.

Ширина дверей транспортного засобу дає можливість швидше робити висадку та посадку пасажирів, що у свою чергу впливає на час простою на зупинках маршруту міського пасажирського транспорту.

Кількість пасажирів, які увійшли до транспортного засобу, також впливає на час простою транспортного засобу на зупинках. Це пояснюється тим, що більша кількість пасажирів, які входять до транспортного засобу, збільшує час посадки. Це, у свою чергу, впливає на час простою транспортних засобів на зупинках міського пасажирського транспорту.

Час простою на зупинках міського пасажирського транспорту буде збільшуватися при збільшенні кількості пасажирів, які виходять 3 транспортного засобу. Вихід 3 транспортного засобу кожного пасажира займає певний період. Це призводить до збільшення часу простою.

Збільшення коефіцієнта використання місткості також впливає на час простою, збільшуючи його. Така залежність пояснюється тим, що посадка та висадка пасажирів при великому наповненні салону забирає певний час, оскільки пасажирам необхідно обійти тих пасажирів, що перебувають всередині салону і на східцях транспортного засобу.

В результаті проведення статистичних розрахунків можна зробити висновок про допустимість використання розробленої моделі зміни простою пасажирів $\mathrm{y}$ транспортному засобі на зупинках маршруту міського пасажирського транспорту для оцінки якості проектів міського пасажирського транспорту.

Висновки 3 дослідження і перспективи, подальший розвиток у даному напрямку. Запропонований комплексний показник якості перевезення пасажирів придатний для оцінки якості транспортного обслуговування пасажирів міським транспортом. Зміна часу простою пасажирів у транспортному засобі на зупинному пункті маршруту 3 достатньою точністю описується нелінійним регресійним рівнянням, в якому як змінні використовуються кількість та ширина дверей, пасажирообмін зупинки, коефіцієнт використання місткості. Подальший розвиток досліджень у даному напрямку полягає у визначенні закономірностей зміни інших показників якості перевезення пасажирів та використання їх для планування якості в проектах міського пасажирського транспорту. 


\section{Список використаних джерел}

1. Аулін, В.В. Удосконалення роботи міського пасажирського транспорту впровадженням центральної диспетчерської системи [Текст] / В.В. Аулін, Д.В. Голуб // Вісник СевНТУ. Сер. Машиноприладобудування та транспорт. - Севастополь, 2011. - С. 9598.

2. Логистика: общественный пассажирский транспорт [Текст]: учеб. Доп. УМО вузов РФ по образ. в обл. транспортных машин / Л.Б. Миротин, Ы.Э. Ташбаев, В.А. Гудков [и др.]; под ред. Л.Б. Миротина; МАДИ (ГТУ). - М.: Экзамен, 2003. - 224 с.

3. Лапидус, В.А. Всеобщее качество (TQM) в российских компаниях [Текст] / В.А. Лапидус; Гос. ун-т управления; Нац. фонд подготовки кадров. - М.: ОАО "Типография "Новости", 2000. - 432 с.

4. Віниченко, В.С. Аналіз факторів і умов, які впливають на якість пасажирських перевезень на міському пасажирському транспорті [Текст] / В.С. Віниченко, І.Ю. Тарасюк // Наук.-техн. збірник. - 2011. - № 99. - С. 369-374.

5. Cronin, J.J. Measuring service quality: a reexamination and extension / J.J. Cronin, S.A. Taylor // Journal of Marketing. -1992. - 56(3). - P. 55 - 68.

6. Parasuraman, A. SERVQUAL: a multiple item scale for measuring consumer perceptions of service quality / A. Parasuraman, V. A. Zeithaml, L. L. Berry // Journal of Retailing. - 1988. 64(1). - P. 12-37.

7. Гудков, В.А. Теория транспортных процессов и систем [Текст] / В.А. Гудков, А.В. Вельможин, Л.Б. Миротин. - М.:Транспорт, 1998. - 218 с.

8. Gabriella Mazzulla. A Service Quality experimental measure for public transport / Laura Eboli, Gabriella Mazzulla. - European Transport /Trasporti Europein, 2006. - №34. - P. 42-53.

9. Prioni, P. Measuring service quality in scheduled bus services / P. Prioni, D.A. Hensher // Journal of Public Transportation . - 2000. - №3(2). - P. 51 - 74.

10. Marcucci E. Local public transport, service quality and tendering contracts in Venezia [Texт] / E. Marcucci, E. Valeri, A. Stathopoulos, V. Gatta // Urban Sustainable Mobilità. - Milano, 2011. - Р. 1-14.

11. Гудков, В.А. Технология, организация и управление пассажирскими автомобильными перевозками [Текст]: учеб. для вузов / В.А. Гудков, Л.Б. Миротин; под ред. Л.Б. Миротина. - М.: Транспорт, 1997. - 312 с.

12. Большаков, А.М. Повышение уровня обслуживания пассажиров автобусами на основе комплексной системы управления качеством [Текст]: дис... канд. экон. наук / А.М. Большаков. - М., 1981. - 174 с.

13. Тарханова, Н.В. Анализ показателей качества пассажирских перевозок [Текст] / Н.В. Тарханова // Совершенствование организации дорожного движения и перевозка пассажиров и грузов: сб. науч. статей Междунар. науч.-практ. конф. - Минск: БНТУ, 2009. C. 33-38.

14. Gabriela Beirão. Enhancing service quality in public transport systems [Texт] / Gabriela Beirão, JoséSarsfield Cabral // Faculty of Engineering. XII: Urban Transport and the Environment in the 21-st Century. - 2006. - P.837 - 845.

15. Гамула, П.Р. Метрологія, стандартизація, управління якістю і сертифікація [Текст] / П.Р. Гамула. - Львів: Видавн. нац. ун-ту "Львівська політехніка", 2004. - 506 с.

16. Margareta Friman. Service supply and customer satisfaction in public transportation: The quality paradox / Margareta Friman, Markus Fellesson / Karlstad University, Sweden. Journal of public transportation, 2009. - vol. 12, no. 4. - P. 57-69. 
17. Friman, M. Implementing quality improvements in public transport / Friman M. // Journal of Public transportation. - 2004. - P. 49-65.

18. Галушко, В.Г. Вероятностно-статистические методы на автотранспорте [Текст] / В.Г. Галушко. - К.: Вища школа, 1976. - 232 с.

Чумаченко Ігор Володимирович, д-р техн. наук, професор, завідувач кафедри управління проектами в міському господарстві і будівництві Харківського національного університету міського господарства імені O.М. Бекетова. Тел.: (057) 707-31-32. E-mail: pmkaf@kname.edu.ua.

Давідіч Наталія Василівна, аспірант кафедри управління проектами в міському господарстві і будівництві Харківського національного університету міського господарства імені О.М. Бекетова. Тел.: (057) 707-31-32. E-mail: pmkaf@ kname.edu.ua.

Chumachenko Igor Vladimirovich, $d$-r of Technical Sciences, Full Professor, head project management in urban economy and construction department, O. M. Beketov Kharkiv National University of Urban Economy. Tel.: (057) 707-31-32.Email: pmkaf@kname.edu.ua.

Davidich Natalia Vasylivna, post-graduate student, O. M. Beketov Kharkiv National University of Urban Economy. Tel.: (057) 707-31-32. E-mail: pmkaf@kname.edu.ua.

Прийнята 25.03.2016 p. 